\title{
Neurological Disorders in Libya: An Overview
}

\author{
Hani T.S. Benamer \\ Neurology Department, Queen Elizabeth Neuroscience Centre, Queen Elizabeth University Hospital, \\ Birmingham, UK
}

\section{Key Words}

Neurological disorders · Libya • Burden estimate

\begin{abstract}
The aim of this study was to review all publications related to the incidence and prevalence of neurological disorders in Libya, and to estimate the burden of these disorders in the country. The PubMed and the Libyan Medical Index were searched using different combinations of keywords. The references in all relevant papers were reviewed for any additional publications. An estimation of the number of patients with neurological disorders was made based on the reviewed data and adjusted using the Libyan Nationwide Official Census of 2006. Sixteen papers were identified. Incidence rate is available for twelve disorders and the prevalence rate for nine. Data for some of the most common neurological problems such as headaches, or for important disorders such as dementia, are lacking. Therefore, the estimate of 6,892 new neurological cases per year and a total of 11,908 neurological patients in 2006 in Libya is largely underestimating the burden of the neurological disorders in this country and should be regarded as the lowest possible estimation. Further neuroepidemiological studies in Libya are needed.

Copyright $\odot 2007$ S. Karger AG, Basel
\end{abstract}

\section{Introduction}

Neurological disorders are defined as diseases related to all structural disorders of the central and peripheral nervous system, as well as muscle diseases. Common conditions that are not caused by structural diseases such as headaches and conditions caused by disordered physiology such as epilepsy are also considered as neurological disorders [1]. The majority of neurological diseases are chronic and usually treated in an outpatient setting. However, different studies in the UK showed that around $20 \%$ of all acute medical admissions were patients suffering from neurological disorders [2, 3].

Libya is an Arabic, North African country with an estimated surface area of $1,775,500 \mathrm{~km}^{2}$ and a population of 5.3 million with $32 \%$ of the population below the age of 15, according to the Libyan Nationwide Official Census of 2006 (www.tedad-Libya.inf).

Most of the populations live in the coastal area in the main cities, namely Tripoli and Benghazi. The Libyan people are generally affluent with the highest per capita income in Africa.

The aim of this paper was to review all the studies of the incidence and prevalence rates related to neurological disorders in Libya, and to estimate the burden of these disorders in the country. To the best of my knowledge no similar work has been carried out on this subject.

Hani T.S. Benamer

Neurology Department, Queen Elizabeth Neuroscience Centre

Queen Elizabeth University Hospital, Edgbaston

Birmingham B15 2TH (UK)

Tel. +44 121697 8221, Fax +44 121697 8402, E-Mail benamer@doctors.org.uk

\begin{tabular}{ll}
\hline KARGER & ( 2007 S. Karger AG, Basel \\
0251-5350/07/0294-0143\$23.50/0 \\
$\begin{array}{l}\text { Fax +4161306 1234 } \\
\begin{array}{l}\text { E-Mail karger@karger.ch } \\
\text { www.karger.com }\end{array}\end{array}$ & $\begin{array}{l}\text { Accessible online at: } \\
\text { www.karger.com/ned }\end{array}$
\end{tabular}

www.karger.com $\quad$ www.karger.com/ned 


\section{Methods}

Searching the PubMed using the keywords 'Libya', and 'Libya' combined with 'incidence', 'prevalence', 'epidemiology', 'neurology', 'neurological diseases' and 'neurological disorders' identified publications related to the neurological disorders in Libya. The references in all relevant papers were reviewed for any additional publications. The newly established database 'Libyan medical index' (www.lmi.com.ly) was also searched. The search was limited to the English language. The literature preceding 31 May 2007 was included.

An estimation of the number of patients with neurological disorders was made based on the reviewed published incidence and prevalence rates which were then adjusted using the Libyan $\mathrm{Na}$ tionwide Official Census of 2006 that showed a total Libyan population of 5,323,991, of which 3,599,278 were above 15 years of age (www.tedad-Libya.inf)

\section{Results}

Twenty-four published reports related to neurology disorders in Libya were identified. Eight papers were excluded, being case reports and clinical series. Sixteen papers are included in this review as they contain data related to the incidence and the prevalence of various neurological disorders in Libya [4-19]. Publication dates range from 1985 to 1995.

All the studies were conducted in Benghazi/Libya. The health service at the time of the studies was based on walk-in polyclinics, four university hospitals and a rehabilitation centre. The neurology unit was based in one of the university hospitals (The Seventh of April Hospital). Medical care is free in Libya. No private medical service was available in the 1980s when the majority of the studies were conducted. Trained neurologists conducted all the studies by searching all medical facilities in Benghazi to identify all patients with specific neurological disorders, the subjects of each study. The studied population in Benghazi was 518,745 . The majority of Benghazi's population are of Arabic descent but a small minority are of Turkish, Greek and Black descent.

The incidence and prevalence of studied neurological disorders in Benghazi/Libya are summarised in tables 13. Table 1 shows the age- and sex-specific annual incidence rates of eight neurological disorders. Table 2 shows the age- and sex-specific prevalence rates of nine neurological disorders. Table 3 shows the age- and sex-specific annual incidence rates for five rare neurological disorders.

Table 4 shows the estimated number of patients with nineteen neurological disorders.
The case-fatality ratio during the first month of the onset of stroke was $17.3 \%$. The ratio was $13 \%$ for patients with ischaemic stroke and 35\% for patients with cerebral haemorrhage [4]. The crude death rate from Parkinson's disease was 1.6 per 100,000 [5]. The mortality rate of patients with acute bacterial meningitis was 30 , and $7.5 \%$ of patients with Guillain-Barré syndrome died during their illness $[7,13]$.

\section{Discussion}

This review summarises all published incidence and prevalence data related to neurological disorders in Libya. This paper also attempts, for the first time, to estimate the burden of the various neurological diseases in Libya. The data are presented in a format to help identify the gaps in the neuroepidemiological data related to Libya and to help in planning and organising further neurological studies and services in the country.

The estimation of the burden of the neurological disorders in Libya using the published data, which are summarised in this paper, has several limitations: (a) the incidence and prevalence studies that are available are limited to certain neurological disorders (incidence rate is available for twelve disorders and the prevalence rate for nine), (b) the lack of data for some of the most common neurological problems such as headaches and important disorders such as dementia, (c) all the studies are hospital based, hence the lack of any door-to-door epidemiological studies. It follows that the estimate of 6,892 new neurological cases per year and a total of 11,908 of neurological patients in 2006 in Libya is largely underestimating the burden of the neurological disorders in this country and should be regarded as the lowest possible estimate.

It is not surprising that cerebrovascular diseases and epilepsy are the most common neurological disorders, especially since the studies were hospital-based and there were no data available for headache disorders. However, neurogenetic conditions also represented a significant portion of the neurological disease burden in the country (13\% of the total estimated neurological cases: 1,566 cases). This is almost equal to the number of Parkinson's disease patients, and 7 times more than multiple sclerosis. This is likely to be related to the structure of the Libyan society. Like in many other Arabic countries, the Libyan populations are characterised demographically by large family units, high birth rates and high rates of consanguineous marriages (up to $50 \%$ of marriages), making 
Table 1. Age- and sex-specific incidence rates for neurological diseases (per 100,000 per year) in Benghazi/Libya

\begin{tabular}{|c|c|c|c|c|c|c|}
\hline Neurological disorder & Study & $\begin{array}{l}\text { Study dura- } \\
\text { tion, years }\end{array}$ & Age, years & Male & Female & $\begin{array}{l}\text { Total } \\
\text { population }\end{array}$ \\
\hline \multirow[t]{19}{*}{ Cerebrovascular disease } & \multirow[t]{9}{*}{ Ashok et al. [4] } & \multirow[t]{9}{*}{1} & $<30$ & 3 & 5 & 4 \\
\hline & & & $30-39$ & 101 & 89 & 96 \\
\hline & & & $40-49$ & 152 & 195 & 172 \\
\hline & & & $50-59$ & 317 & 263 & 292 \\
\hline & & & $60-69$ & 390 & 310 & 348 \\
\hline & & & $\geq 70$ & 545 & 354 & 457 \\
\hline & & & $>15$ & - & - & 131.1 \\
\hline & & & $15-69$ & - & - & 92.9 \\
\hline & & & all ages & 69 & 58 & 63 \\
\hline & \multirow[t]{7}{*}{ Radhakrishnan et al. [14] } & \multirow[t]{7}{*}{1} & $15-19$ & 0 & 9.8 & 4.7 \\
\hline & & & $20-24$ & 16.9 & 24.2 & 20.4 \\
\hline & & & $25-29$ & 19.5 & 19.6 & 19.6 \\
\hline & & & $30-34$ & 92.9 & 58.9 & 76.6 \\
\hline & & & $35-40$ & 107.9 & 117.5 & 112.6 \\
\hline & & & $15-40$ & 39.3 & 40.3 & 39.8 \\
\hline & & & age-adjusted rate & 47.7 & 46.1 & 47 \\
\hline & \multirow[t]{3}{*}{ El Zunni et al. [6] } & \multirow[t]{3}{*}{3} & $15-45$ & 14 & 15 & - \\
\hline & & & $>45$ & 162 & 133 & - \\
\hline & & & all ages & - & - & 48 \\
\hline Parkinson's disease & Ashok et al. [5] & 2.5 & all ages & & & 4.5 \\
\hline \multirow[t]{2}{*}{ Multiple sclerosis } & \multirow[t]{2}{*}{ Radhakrishnan et al. [8] } & \multirow[t]{2}{*}{2} & $10-50$ & & & 0.8 \\
\hline & & & all ages & & & 0.4 \\
\hline \multirow[t]{8}{*}{ Motor neuron disease } & \multirow[t]{8}{*}{ Radhakrishnan et al. [16] } & \multirow[t]{8}{*}{5} & $0-29$ & 0.11 & 0 & 0.05 \\
\hline & & & $30-39$ & 2.32 & 0.81 & 1.58 \\
\hline & & & $40-49$ & 2.84 & 2.17 & 2.53 \\
\hline & & & $50-59$ & 8.14 & 3.76 & 6.10 \\
\hline & & & $60-69$ & 8.11 & 2.27 & 5.35 \\
\hline & & & $\geq 70$ & 0 & 2.56 & 1.25 \\
\hline & & & all ages & 1.19 & 0.56 & 0.89 \\
\hline & & & adjusted rate & 1.17 & 0.57 & 0.87 \\
\hline \multirow{14}{*}{$\begin{array}{l}\text { Idiopathic intracranial } \\
\text { hypertension }\end{array}$} & \multirow[t]{3}{*}{ Radhakrishnan et al. [15] } & \multirow[t]{3}{*}{2} & $>15$ & - & - & 3.6 \\
\hline & & & female only population & & & 3.6 \\
\hline & & & all ages & - & - & 1.7 \\
\hline & \multirow[t]{11}{*}{ Radhakrishnan et al. [9] } & \multirow[t]{11}{*}{$7^{1}$} & $0-14$ & 0.21 & 0 & 0.11 \\
\hline & & & $15-19$ & 0.64 & 6.32 & 3.34 \\
\hline & & & $20-29$ & 0.43 & 12.55 & 6.37 \\
\hline & & & $30-39$ & 0 & 19.12 & 9.33 \\
\hline & & & $40-49$ & 0.68 & 3.88 & 2.16 \\
\hline & & & $50-59$ & 0 & 1.34 & 0.62 \\
\hline & & & $\geq 60$ & 0 & 0 & 0 \\
\hline & & & all ages & 0.27 & 4.32 & 2.23 \\
\hline & & & age-adjusted rate & 0.26 & 5.92 & 3.17 \\
\hline & & & women aged 15-44 & - & 12 & - \\
\hline & & & obese women aged 15-44 & - & 21.4 & - \\
\hline \multirow[t]{9}{*}{ Bell's palsy } & Sridharan et al. [17] & 2 & $0-9$ & 4.4 & 4.05 & 4.24 \\
\hline & & & $10-19$ & 21.85 & 19.2 & 20.6 \\
\hline & & & $20-29$ & 34.7 & 39.25 & 36.9 \\
\hline & & & $30-39$ & 36.75 & 38.55 & 37.65 \\
\hline & & & $40-49$ & 47.35 & 51.55 & 49.3 \\
\hline & & & $50-59$ & 52.85 & 75.2 & 63.2 \\
\hline & & & $\geq 60$ & 43.65 & 40.85 & 42.3 \\
\hline & & & all ages & 23 & 23.7 & 23.35 \\
\hline & & & age-adjusted rate & 33.3 & 38.02 & 35.72 \\
\hline
\end{tabular}


Table 1 (continued)

\begin{tabular}{|c|c|c|c|c|c|c|}
\hline Neurological disorder & Study & $\begin{array}{l}\text { Study dura- } \\
\text { tion, years }\end{array}$ & Age, years & Male & Female & $\begin{array}{l}\text { Total } \\
\text { population }\end{array}$ \\
\hline $\begin{array}{l}\text { Central nervous system } \\
\text { infection }\end{array}$ & Radhakrishnan et al. [7] & 2 & $>15$ & & & 8.6 \\
\hline Guillain-Barré syndrome & Radhakrishnan et al. [13] & 3 & $\begin{array}{l}0-9 \\
10-19 \\
20-29 \\
30-39 \\
40-49 \\
50-59 \\
\geq 60 \\
\text { all ages } \\
\text { age-adjusted rate }\end{array}$ & $\begin{array}{l}0 \\
2.3 \\
4 \\
3.9 \\
1.6 \\
0 \\
2.1 \\
1.62 \\
1.61\end{array}$ & $\begin{array}{l}0.7 \\
1.2 \\
2.1 \\
8.1 \\
1.8 \\
3.1 \\
0 \\
1.86 \\
1.85\end{array}$ & $\begin{array}{l}0.3 \\
1.8 \\
3.1 \\
5.9 \\
1.7 \\
1.5 \\
1.1 \\
1.74 \\
1.73\end{array}$ \\
\hline
\end{tabular}

${ }^{1}$ This study was an extension of the first study on idiopathic intracranial hypertension and included data from the original study.

Table 2. Age- and sex-specific prevalence rates for neurological diseases (per 100,000) in Benghazi/Libya

\begin{tabular}{|c|c|c|c|c|c|c|}
\hline Neurological disorder & Study & $\begin{array}{l}\text { Study dura- } \\
\text { tion, years }\end{array}$ & Age, years & Male & Female & $\begin{array}{l}\text { Total } \\
\text { population }\end{array}$ \\
\hline Epilepsy & Sridharan et al. [18] & 2 & $\begin{array}{l}15-24 \\
25-34 \\
35-44 \\
45-59 \\
\geq 60 \\
>15 \\
\text { age-adjusted rate }\end{array}$ & $\begin{array}{r}370 \\
290 \\
170 \\
90 \\
110 \\
240 \\
210\end{array}$ & $\begin{array}{r}350 \\
200 \\
180 \\
120 \\
80 \\
210 \\
170\end{array}$ & $\begin{array}{l}360 \\
250 \\
180 \\
100 \\
100 \\
230 \\
190\end{array}$ \\
\hline Parkinson's disease & Ashok et al. [5] & 2.5 & $\begin{array}{l}<40 \\
40-49 \\
50-59 \\
60-69 \\
\geq 70 \\
\text { all ages } \\
\text { age-adjusted rate }\end{array}$ & $\begin{array}{r}0 \\
14.2 \\
81.4 \\
219.5 \\
544.5 \\
32.5 \\
58.2\end{array}$ & $\begin{array}{c}0.5 \\
32.6 \\
103.3 \\
155 \\
501.3 \\
30.3 \\
62.1\end{array}$ & $\begin{array}{r}0.2 \\
22.8 \\
91.5 \\
185.7 \\
524.6 \\
31.4 \\
60.1\end{array}$ \\
\hline Multiple sclerosis & Radhakrishnan et al. [8] & 2 & $\begin{array}{l}0-14 \\
15-19 \\
20-29 \\
30-39 \\
40-49 \\
50-59 \\
\geq 60 \\
\text { all ages } \\
\text { age-adjusted rate }\end{array}$ & $\begin{array}{c}0 \\
0 \\
6 \\
7.7 \\
14.2 \\
8.1 \\
0 \\
3 \\
5.4\end{array}$ & $\begin{array}{c}0 \\
14.7 \\
6.3 \\
28.4 \\
5.4 \\
0 \\
0 \\
5.2 \\
6.4\end{array}$ & $\begin{array}{c}0 \\
7 \\
6.2 \\
17.8 \\
10.1 \\
4.4 \\
0 \\
4 \\
5.9\end{array}$ \\
\hline Motor neuron disease & Radhakrishnan et al. [16] & 5 & $\begin{array}{l}0-29 \\
30-39 \\
40-49 \\
50-59 \\
60-69 \\
\geq 70 \\
\text { all ages } \\
\text { adjusted rate }\end{array}$ & $\begin{array}{c}0.53 \\
7.74 \\
9.47 \\
32.55 \\
30.42 \\
0 \\
4.48 \\
4.39\end{array}$ & $\begin{array}{l}0 \\
4.06 \\
10.85 \\
18.78 \\
0 \\
12.79 \\
2.39 \\
2.45\end{array}$ & $\begin{array}{r}0.27 \\
5.94 \\
10.11 \\
26.16 \\
16.06 \\
6.26 \\
3.47 \\
3.42\end{array}$ \\
\hline
\end{tabular}


Table 2 (continued)

\begin{tabular}{|c|c|c|c|c|c|c|}
\hline Neurological disorder & Study & $\begin{array}{l}\text { Study dura- } \\
\text { tion, years }\end{array}$ & Age, years & Male & Female & $\begin{array}{l}\text { Total } \\
\text { population }\end{array}$ \\
\hline Hereditary cerebellar ataxia & Sridharan et al. [19] & 2 & all ages & - & - & 2.7 \\
\hline Hereditary spastic paraplegia & Sridharan et al. [19] & 2 & all ages & - & - & 2.1 \\
\hline Spinal muscular atrophy & Radhakrishnan et al. [10] & 4 & $\begin{array}{l}\text { childhood } \\
\text { adult } \\
\text { distal }\end{array}$ & $\begin{array}{l}- \\
- \\
-\end{array}$ & $\begin{array}{l}- \\
- \\
-\end{array}$ & $\begin{array}{l}2.3 \\
0.6 \\
0.6\end{array}$ \\
\hline Muscular dystrophy & Radhakrishnan et al. [13] & 3 & all ages & - & - & 13.2 \\
\hline $\begin{array}{l}\text { Hereditary sensory and } \\
\text { motor neuropathy }\end{array}$ & Radhakrishnan et al. [13] & 4 & all ages & - & - & 7.9 \\
\hline
\end{tabular}

Table 3. Age- and sex-specific incidence rates for some rare neurological diseases (per million per year) in Benghazi/Libya

\begin{tabular}{|c|c|c|c|c|c|c|}
\hline Neurological disorder & Study & $\begin{array}{l}\text { Study dura- } \\
\text { tion, years }\end{array}$ & Age & Male & Female & $\begin{array}{l}\text { Total } \\
\text { population }\end{array}$ \\
\hline \multirow[t]{5}{*}{ Polymyositis } & \multirow[t]{5}{*}{ Radhakrishnan et al. [13] } & \multirow[t]{5}{*}{3} & $<20$ & 4.1 & 6.6 & 5.4 \\
\hline & & & $20-40$ & 5.6 & 29.4 & 17.3 \\
\hline & & & $>40$ & 6.7 & 7.6 & 7.2 \\
\hline & & & all ages & 4.9 & 11.9 & 8.4 \\
\hline & & & adjusted rate & 4.9 & 12.6 & 8.8 \\
\hline \multirow[t]{6}{*}{ Myasthenia gravis } & \multirow[t]{6}{*}{ Radhakrishnan et al. [11] } & \multirow[t]{6}{*}{4} & $<20$ & 0 & 6.7 & 3.3 \\
\hline & & & 20-39 & 0 & 13.3 & 6.5 \\
\hline & & & $40-59$ & 7.5 & 0 & 4 \\
\hline & & & $>60$ & 13.9 & 0 & 7.2 \\
\hline & & & all ages & 1.9 & 7 & 4.3 \\
\hline & & & adjusted rate & 2.1 & 6.8 & 4.4 \\
\hline Progressive supranuclear palsy & Radhakrishnan et al. [11] & 4 & all ages & - & - & 3 \\
\hline Subacute sclerosing panencephalitis & Radhakrishnan et al. [11] & 4 & all ages & - & - & 2.4 \\
\hline Creutzfeldt-Jakob disease & Radhakrishnan et al. [12] & 4 & all ages & - & - & 0.48 \\
\hline
\end{tabular}

genetic diseases a common health issue [20]. These factors should be taken into consideration when further planning neurology services.

The two studies from Benghazi about the incidence of cerebrovascular diseases showed different results. The first study was a 12-month study from November 1983 to October 1984 and showed an incidence rate of 63 per 100,000 . The second one was a 3 -year study from January 1991 to December 1993 and showed an incidence rate of 48 per 100,000. The two studies from Benghazi looked at the same population and used the same methods. It is unlikely that these results represent a true general decline in the incidence of stroke in Benghazi/Libya in such a short period of time; instead, case ascertainment is the likely explanation. The first study was conducted in the mid-1980s [4], the time when private medical practice was banned in Libya, while the second study was conducted in the early 1990s [6], after the opening up of the private medical sector. It is likely that many patients elected to be treated in the newly established private sector rather than in the university hospitals, leading to a false reduction in the recorded cases of cerebrovascular diseases. Therefore, a well-designed epidemiological study of such an important neurological disorder is urgently required. 
Table 4. Estimated number of patients with neurological disorders in Libya

\begin{tabular}{llrl}
\hline Neurological disorder & $\begin{array}{l}\text { Study on which the } \\
\text { estimation is based }\end{array}$ & $\begin{array}{l}\text { Estimated } \\
\text { new cases per year }\end{array}$ & $\begin{array}{c}\text { Estimated total } \\
\text { number of cases }\end{array}$ \\
\hline Cerebrovascular disease & Ashok et al. [4] & $4,719^{1}$ & - \\
Epilepsy & Sridharan et al. [18] & - & $8,272^{1}$ \\
Parkinson's disease & Ashok et al. [5] & 240 & 1,672 \\
Multiple sclerosis & Radhakrishnan et al. [8] & 21 & 213 \\
Motor neuron disease & Radhakrishnan et al. [16] & 47 & 185 \\
Idiopathic intracranial hypertension & Radhakrishnan et al. [9] & 119 & - \\
Bell's palsy & Sridharan et al. [17] [1] & 1,243 & - \\
Central nervous system infection & Radhakrishnan et al. [7] & $310^{1}$ & - \\
Guillain-Barré syndrome & Radhakrishnan et al. [13] & 93 & - \\
Hereditary cerebellar ataxia & Sridharan et al. [19] & - & 144 \\
Hereditary spastic paraplegia & Sridharan et al. [19] [19] & - & 112 \\
Spinal muscular atrophy & Radhakrishnan et al. [10] & - & 186 \\
Muscular dystrophy & Radhakrishnan et al. [13] & - & 703 \\
Hereditary sensory and motor neuropathy & Radhakrishnan et al. [10] & - & 421 \\
Polymyositis & Radhakrishnan et al. [13] & Radhakrishnan et al. [11] & - \\
Myasthenia gravis & Radhakrishnan et al. [11] & 23 & - \\
Progressive supranuclear palsy & Radhakrishnan et al. [11] & 16 & - \\
Subacute sclerosing panencephalitis & Radhakrishnan et al. [12] & 13 & - \\
Creutzfeldt-Jakob disease & & 3 & - \\
\hline
\end{tabular}

${ }^{1}$ Above the age of 15 .

Neurological disorders, and neurosciences in general, usually have a low profile especially in comparison with heart diseases, cancer and diabetes. According to the World Health Organisation (http://www.emro.who.int/ $\mathrm{mnh} /$ whd/CountryProfile-LIY.htm) the main causes of hospital mortality in Libya in 1987 were injury and poisoning (15.5\%); diseases of the circulatory system (11.6\%); certain conditions originating in the perinatal period (11.4\%); diseases of the respiratory system (7\%), and neoplasm (4.4\%). Neurological disorders do not appear on the list of the main causes of mortality, as the diseases of the nervous system tend to be chronic and disabling rather than a direct cause of death. Also, neurological disorders such as epilepsy have social stigma attached to them, leading to major psychological and behavioural difficulties. Therefore, raising the profile of neurosciences is important to provide a better service to patients. Accurate estimation of the burden of neurological disorders based on good epidemiological studies is an essential first step to increase the public awareness about neurological disorders.

Neurological conditions are one of the main causes of chronic disabilities. Studies from the UK estimated that $33 \%$ of epilepsy patients, $60 \%$ of stroke patients, $85 \%$ of Parkinson's disease patients, $50 \%$ of multiple sclerosis pa- tients and $93 \%$ of motor neuron disease patients have a significant disability $[1,21]$. This has a significant impact on patients, their families, and the society as a whole. No specific data are available from Libya; therefore, studies to assess the extent and the effect of disabilities related to neurological disorders in Libya are essential.

It is clearly highlighted in this paper that despite the availability of some good epidemiological data, further studies are essential to cover all neurological disorders and other important aspects related to these conditions such as mortality rate and long-term disabilities, and their implication for the health service and the Libyan society. This will allow for a more accurate estimation of the burden of the neurological disorders in Libya.

\footnotetext{
References 1 Neurology in the United Kingdom. London, Association of British Neurologists, 1997.

2 Morrow JI, Patterson VH: The neurological practice of a district general hospital. J Neurol Neurosurg Psychiatry 1987;50:13971401.

3 Playford ED, Crawford P, Monro PS: A survey of neurological disability at a district general hospital. Br J Clin Pract 1994;48: 304-306.
} 
4 Ashok PP, Radhakrishnan K, Sridharan R, el-Mangoush MA: Incidence and pattern of cerebrovascular diseases in Benghazi, Libya. J Neurol Neurosurg Psychiatry 1986;49:519523.

5 Ashok PP, Radhakrishnan K, Sridharan R, Mousa ME: Epidemiology of Parkinson's disease in Benghazi, North-East Libya. Clin Neurol Neurosurg 1986;88:109-113.

-6 El Zunni S, Ahmed M, Prakash PS, Hassan K: Stroke: incidence and pattern in Benghazi, Libya. Ann Saudi Med 1995;15:367-369.

7 Radhakrishnan K, Maloo JC, Poddar SK, Mousa ME: Central nervous system infections in Benghazi, Libya: experience from a community-based adult medical neurology set-up. J Trop Med Hyg 1987;90:123-126.

-8 Radhakrishnan K, Ashok PP, Sridharan R, Mousa ME: Prevalence and pattern of multiple sclerosis in Benghazi, north-eastern Libya. J Neurol Sci 1985;70:39-46.

-9 Radhakrishnan K, Thacker AK, Bohlaga NH, Maloo JC, Gerryo SE: Epidemiology of idiopathic intracranial hypertension: a prospective and case-control study. J Neurol Sci $1993 ; 116: 18-28$.
Radhakrishnan K, Thacker AK, Maloo JC: A clinical, epidemiological and genetic study of hereditary motor neuropathies in Benghazi, Libya. J Neurol 1988;235:422-424.

11 Radhakrishnan K, Thacker AK, Maloo JC, Gerryo SE, Mousa ME: Descriptive epidemiology of some rare neurological diseases in Benghazi, Libya. Neuroepidemiology 1988; 7:159-164.

2 Radhakrishnan K, Mousa ME: CreutzfeldtJakob disease in Benghazi, Libya. Neuroepidemiology 1988;7:42-43.

13 Radhakrishnan K, el-Mangoush MA, Gerryo SE: Descriptive epidemiology of selected neuromuscular disorders in Benghazi, Libya. Acta Neurol Scand 1987;75:95-100.

14 Radhakrishnan K, Ashok PP, Sridharan R, Mousa ME: Stroke in the young: incidence and pattern in Benghazi, Libya. Acta Neurol Scand 1986;73:434-438.

15 Radhakrishnan K, Sridharan R, Ashok PP, Mousa ME: Pseudotumour cerebri: incidence and pattern in North-Eastern Libya. Eur Neurol 1986;25:117-124.
16 Radhakrishnan K, Ashok PP, Sridharan R, Mousa ME: Descriptive epidemiology of motor neuron disease in Benghazi, Libya. Neuroepidemiology 1986;5:47-54.

17 Sridharan R, Radhakrishnan K, Ashok PP, Mousa ME: Clinical and epidemiological study of Bell's palsy in Benghazi, Libya. Afr J Med Med Sci 1988;17:141-144.

18 Sridharan R, Radhakrishnan K, Ashok PP, Mousa ME: Epidemiological and clinical study of epilepsy in Benghazi, Libya. Epilepsia 1986;27:60-65.

19 Sridharan R, Radhakrishnan K, Ashok PP, Mousa ME: Prevalence and pattern of spinocerebellar degenerations in northeastern Libya. Brain 1985;108:831-843.

20 Tadmouri GO, Al Ali TM, Al Khaja N: The Arab world; in Tadmouri GO, Al Ali TM, Al Khaja N (eds): Genetic Disorders in Arab World: United Arab Emirates. Dubai, Centre of Arab Genomic Studies, 2004, pp 1-5.

21 Cockerell OC, Sander JW, Shorvon SD: Neuroepidemiology in the United Kingdom. J Neurol Neurosurg Psychiatry 1993;56:735738. 